Volume and Issues Obtainable at Center for Sustainability Research and Consultancy

Journal of Accounting and Finance in Emerging Economies

ISSN: 2519-0318 \& ISSN (E): 2518-8488

Volume 7: Issue 3 September 2021

Journal homepage: www.publishing.globalcsrc.org/jafee

\title{
Impact of Cash Flow Management Practices on Financial Performance of Cement Manufacturing Firms: A Comparative Study of Pakistan and India
}

* Muhammad Adil Keerio, Mehran University, Institute of Science Technology and Development (MUISTD), Jamshoro, Pakistan

Arifa Bano Talpur, Mehran University, Institute of Science Technology and Development (MUISTD), Jamshoro, Pakistan

Tooba Ameen, Mehran University, Institute of Science Technology and Development (MUISTD), Jamshoro, Pakistan

Meer Hassan Mari, Mehran University, Institute of Science Technology and Development (MUISTD), Jamshoro, Pakistan

*Corresponding author's email address: adilali.2k12@gmail.com

ARTICLE DETAILS

History

Revised format: Aug 2021

Available online: Sep 2021

Keywords

Cash flow Management,

Financial Performance,

Pooled OLS Regression,

Breauch Pagan

JEL Classification

O16, F65

\section{OPEN ACCESS}

ABSTRACT

Purpose: The study examined the impact of cash flow management practices on Pakistani cement firm's financial performance with comparison of Indian cement sector's selected firms.

Methodology: The Pooled OLS Regression is applied with the Help of EViews software. The data collection is from official websites of the concerned companies from 2009 to 2018 with help of secondary source. The multiple regressions, Random Effect Model and Fixed effect models are used for the analysis of data and confirmed with Husman test.

Findings: The finding of this study for both selected countries indicated the influence of cash flow management practices wherein both countries cement producing companies shows significant impact on firm's performance but in terms of Pakistan Return on Assets have no impact on firm's Profitability.

Implications: Therefore, after a careful analysis study recommended that cement manufacturing companies must reevaluate their practices of managing cash flows in order to generate more profitability and generate enough cash to meet their obligations.

(C) 2021 The authors, under a Creative Commons AttributionNonCommercial- 4.0

Recommended citation: Keerio, M. A., Talpur, A. B., Ameen, T. and Mari, M. H. (2021). The Impact of Cash Flow Management Practices on Financial Performance of Cement Manufacturing Firms: A Comparative Study of Pakistan and India. Journal of Accounting and Finance in Emerging Economies, 7(3), 667-682.

\section{Introduction}

The cement industry is the building block as well as important item used for development in 
country's construction industry, which constantly considered as a barometer of improvement in developing country and properly taken as a significant indicator of economic activity. The production of cement at industrial level was started in the middle of nineteenth century, first with shaft incinerators, later these were switched by rotary incinerators as standard equipment around the world. Cements (the concretes that they may be used to build) were increasingly being investigated as an alternative to wood and stone by the time of the industrial revolution. Those seeking to develop the needs for unique construction materials created several outstanding and new cement patents and designs in the late 1700s and early 1800s. China represents a major producer and purchaser of cement, After China, which is unquestionably the world's largest cement production; India was the most significant cement producer in 2010.

Cement is a capital-intensive, energy-intensive, and vital industry for building national infrastructure. However, accounting for a minor percentage of global output, the worldwide cement sector has been growing much faster than local demand in recent years. Cement production firms have been pushed to relocate to nations with less strict environmental restrictions as an outcome effort to protect the environment in emerging countries, particularly Europe. It is broadly utilized in the manufacture of concrete and has offered a trend for economic performance and environmental enforcement, along with continuously increasing real prices. Concrete is made up of inert aggregate particles like sand, gravel, broken rocks, and cement. Cement use and production are intimately connected to the construction industry, and consequently to overall economic activity. Cement is one of the most developed items in the world, and it is created in almost every country due to its importance as a building material and the geographical availability of the key raw materials, namely limestone. The broad development is also attributable to the relatively low price and high density of cement, which reduces ground transportation expenses due to the relatively high prices. Export trade (except plants grown near the border) is generally limited in terms of global production (Abeer.M, 2021).

Because it is required to build and improve infrastructure, cement plays an important social and economic function. This industry, on the other hand, is a major polluter. Cement production contributes about $4 \%$ to global warming by generating $5-6 \%$ of the carbon dioxide produced by human activities. It has the ability to release significant amounts of chronic chemical pollutants such dioxins, heavy metals, and particulate matter. The efficient use of energy is also critical. Cement manufacturing consumes about 0.6 percent of all electricity generated in the United States. The chemistry that drives cement manufacturing and use, on the other hand, can be quite useful in addressing these environmental concerns.

Pakistan's cement industry has grown tremendously since 1947. Undoubtedly, cement is the most essential and broadly used construction material in the Advanced era. The Karachi Stock Exchange lists 21 businesses in the cement industry with a combined net prosperity of roughly Rs. 25 billion. A number of the corporations have multiple factories in different cities. According to All Pakistan Cement Manufacturing Authority, there are right 24 cement plants in Pakistan. The cement production capacity of 57.13 million tons and the utilization capacity is $80.71 \%$. The total dispatch of cement production is 34.58 million tones including local dispatches of 29.45 and Exports of 5.13 million tones. The total capital registered is Rs 67,629.56 million, with a market capitalization of Rs 377,405 million. The benefit after expenses for the sector was Rs 55,185.67 million. (Page\# 44,91, Pakistan Economic Survey 2018-19).

India's cement sector was deregulated in 1982, and the country is now ranked second in the world for cement production. It's no surprise that India's cement business contributes significantly to the country's economy by directly or indirectly employing over a million people. The Indian cement business has received significant investments from both global and domestic firms. India has great ability for advancement within the infrastructure as well as construction sector and 
expecting larger interest from cement sector. A key factor that helps in the development of this sector is the prepared accessibility of the raw materials for producing cement, includes limestone and also coal. The capacity of producing cement is 509 million tons each year (mtpa) as of March 2019 , the main 20 companies record around $70 \%$ of the overall production (IBEF; May 2020) This study purposes to compare the performance of Pakistan and India cement manufacturing industry with the help of cash flow management practices. Both countries follow the same accounting standards provided by IFRS (International Financial Reporting Standards), so their financial statement is understandable.

\section{Problem Statement/Research Gap}

Cement industry is arguably the most important source of material for construction and physical infrastructure and counted among the top 10 manufacturing in the world and there it is required to analyze the influence of cash flow practices of firm's performance specially on cement industry in Pakistan by comparing the impact of cash flow management practices of cement industry with its neighboring country like India, which will worth more and meaningful contribution to knowledge because there is no work done before on comparison of cement industry's cash flow management practices among India and Pakistan.

\section{Research Questions}

Q1: What is the impact of the cash flow management practices on Cement manufacturing firm's financial performance?

Q2: How cash flow management practices differ in India and Pakistan?

\section{Conceptual Framework}

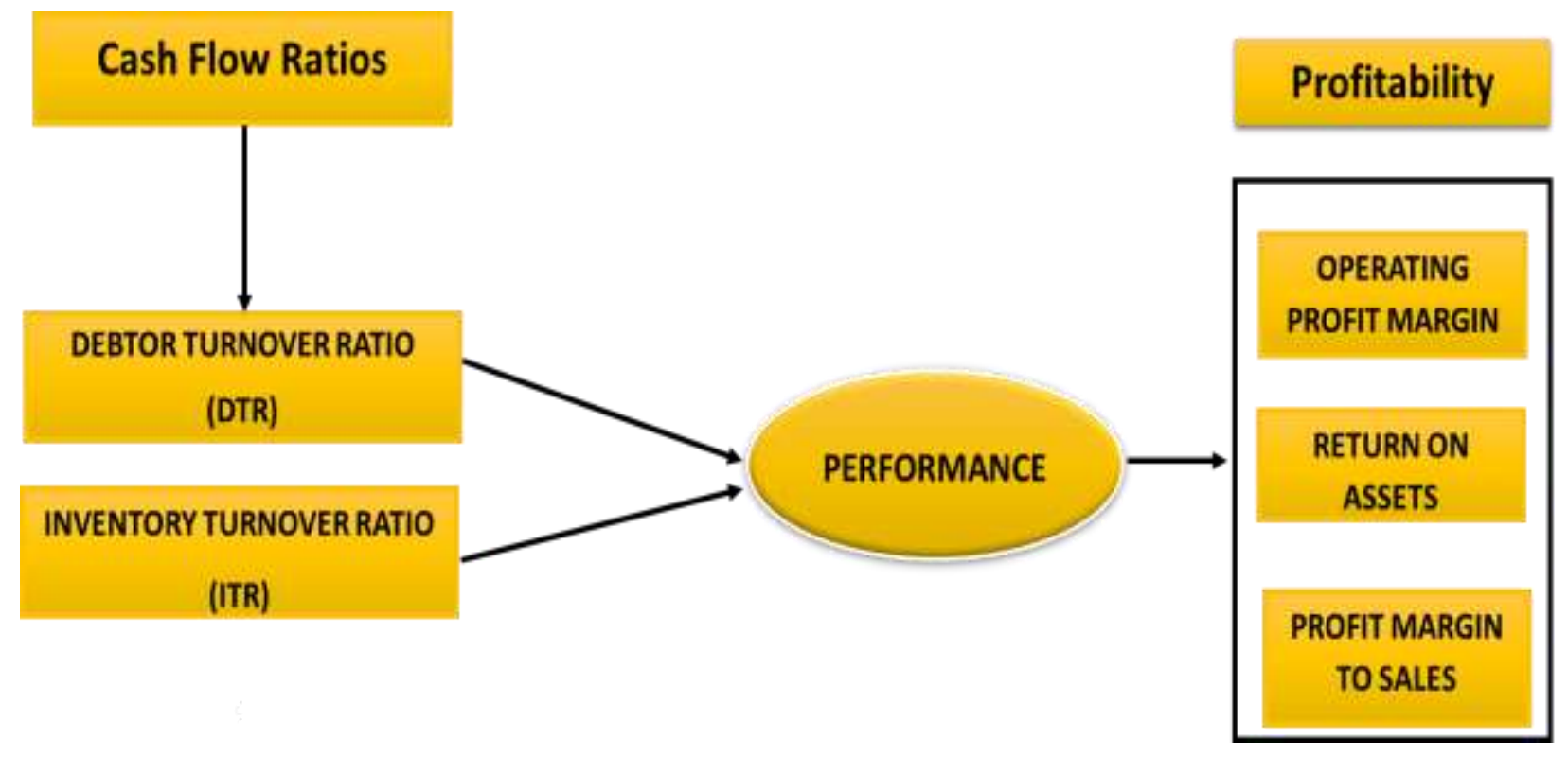

Source: Janaki Samuel (August 2016) International Journal of Economic and Business Review (EPRA)

\section{Literature Review}

Cash flow management mentions a systematic way by which the organizations retain authority over the inflow and outflow of assets and the objective of cash flow management is to make sure that the business does not run into cash deficiencies, a business must not be overdue in receivables of the creditor. Additionally, it must not have long-standing borrowers in its books. The company's performance is largely determined by how it manages its cash flows. Many people underestimate the importance of cash flow management, which leads to many firms failing to realize their full potential. The management of cash flow relies on cash conversation cycle and is counted as an essential element in upgrading the performance of companies. The 
importance of cash flow management is to ensure there is positive cash flow for easy business measures as cash has been considered as the existence blood of any company (Thevaruban, 2016). The practices of management of cash flows of a firm manages working capital as receivables of cash from consumers, inventory stocked, and payments of cash to the raw material providers, are inevitably connected to the performance of firm.

Chintha et al (2021). According to their research, cash management is linked to a number of crucial areas, including the impact on a company's liquidity, performance, insolvency, and allinclusive working capital. To confirm the links between cash management as well as financial performance, 36 firms listed on the Muscat Securities Market (MSM) were chosen across time, commencing in 2014 and ending in 2019. The study employed financial performance statistics such as Return on Assets (ROA), Return on Equity (ROE), and Net Profit Ratio, as well as the Cash Ratio (CR) and Operating Cash to Debt Ratio (OC-DR) (NPR). With ROA, ROE, and NPR Cash Ratio (CR) exhibits a statistically significant positive relationship. The OC-DR has a significant influence on ROA and NPR When Return on Asset was employed as a dependent variable, Overall, the major finding is that cash management strategies used by Omani manufacturing companies account for a significant amount of their financial performance.

Efeeloo et al (2020) The relationship between cash flow management and the financial performance of some selected oil and gas companies which are listed on the stock exchange of Nigeria was investigated experimentally in this study. The Stakeholders' Theory served as the foundation for the project. It used a judgmental research method. Data was gathered from five selected publicly traded companies' annual reports over a 5-year span (2013-2018), correlation and multiple regression methodologies were used to assess the data. Cash flows from operating and investment activities were found to have a negative and insignificant relationship with profitability, whereas cash flows from financing operations were found to have a positive and significant impact on firm performance. in the oil and gas industry.

Thomas et al (2019), In the Kitale region, worked on Agricultural Development Corporation units. The study's major goal was to see how cash flow management affected the performance of agricultural businesses in Trans-Nzoia County. The goal of the research was to determine the impact of stable and healthy liquidity on agricultural firm performance in Trans-Nzoia County. The research used a descriptive design. Using the SPSS version 21 program, the data was cleaned, coded, and analyzed. The link between the independent factors and the dependent variable was determined using a multiple regressions model/analysis. As per the findings of this study, healthy and stable liquidity has a major impact on the functioning of agricultural businesses in Trans Nzoia County.

Bari et al. (2019) believes that good cash management techniques are essential to maintain their company's profitability and long-term viability are in line with their goals. The goal of this study was to learn well about current cash management techniques of food and beverage shops in Puntland, as well as the effects of those practices on their profitability and long-term viability. The study had four desired outcomes relating to the effect of the first cash conversion cycle of Puntland's food and beverage businesses. The second step was to see if the retailers had adequate inventory management systems in place. Third, determining whether the retailer's account receivable management procedures are in place and whether they are favorable to their business's maximum profitability. Fourth, establishing whether food and beverage retailers had account payable management practices in place and assessing their impact on the business. We performed financial analysis based on the research of the sampled shops and discovered that they had a low liquidity ratio in their operations, as well as that the cash flow from different merchants was not consistent. Most retailers said the issue of low liquidity ration stemmed from their inability to pay their liabilities on time owing to fluctuations in the area's food and beverage market patterns. It 
was also clear that the problem emerged as a result of poor management practices, such as retailers' inability to maintain track of their operations and apply the knowledge gathered in

\section{Pakistani Cement Manufacturing Companies Data}

Table 1: Shows independent variables (Debtor Turnover Ration and Inventory Turnover Ratio)

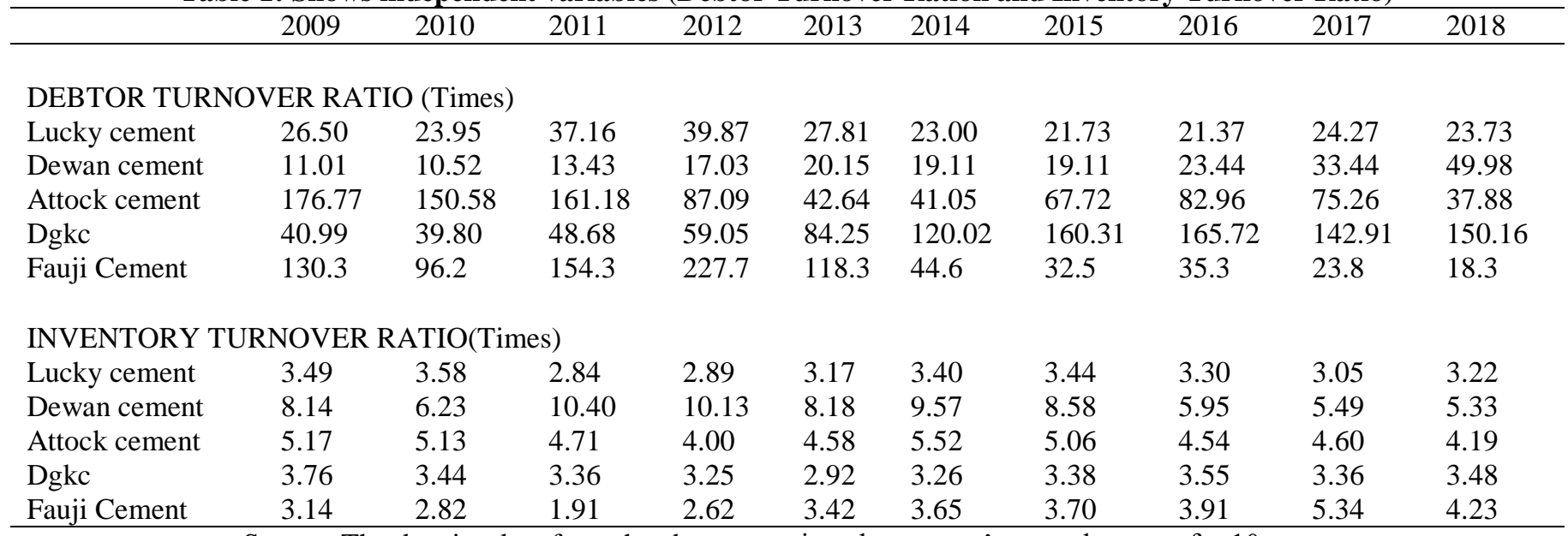

Source: The data is taken from the above-mentioned company's annual reports for 10 years

Table 2: Shows Dependent variables (Operating Profit Margin, Return on Assets and Profit Margin to Sales.

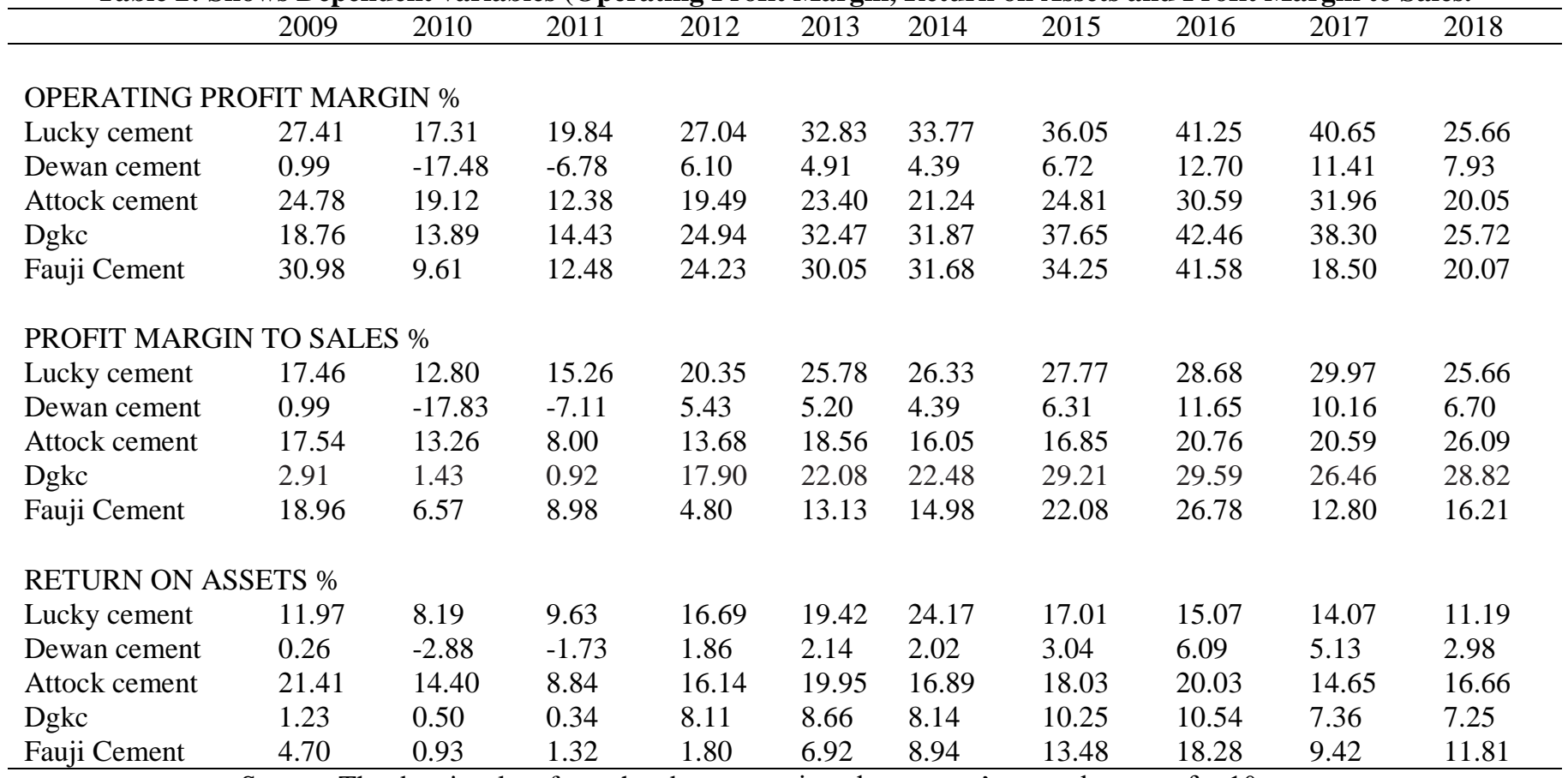

Source: The data is taken from the above-mentioned company's annual reports for 10 years

financial planning and management.

Wadesango et al (2019) The focus of this thesis was to put into sets the current cash flow management strategies used by Zimbabwean SMEs and to investigate how these practices affect their profitability and long-term viability. In this study, both qualitative and quantitative research methods were used. The Yamane formula was used to calculate the sample, which resulted in a total of 50 responses. Data was collected through questionnaires and interviews, The chi square test was used to examine and test these data, which revealed that most SMEs' cash management procedures had a major impact on their profitability and long-term viability. The findings also found that most SMEs are hesitant to implement good cash management techniques, which leads to failure. 


\section{Research Methods \& Material}

This research is based on quantitative methodology, wherein two countries such as Pakistan and India were selected as sample size. The data collection is from official websites of the concerned companies from 2009 to 2018 with help of secondary source. The multiple regression, Random Effect Model and Fixed effect models are used and confirmed with Husman test for the analysis of data with the help of E views tool.

\section{Variables}

The Variables are set based on past literature review and current situation of cash flow management in cement manufacturing firms.

Dependent variable: Profitability measures such as Return on Assets (ROA), Profit Margin to Sales, and Operating Profit Margin are used to assess a company's financial performance.

Independent variables: Cash Flows variables of the firm contains, Debtor Turnover Ratio\& Inventory Turnover Ratio.

\section{Data collection}

The data is collected though the secondary source from Pakistan Stock Exchange \& official websites of relevant companies of India and Pakistan and the period of data collection is from 2009 to 2018. The tables bellow will show the collected data which is further used for data analysis

\section{Indian Cement Manufacturing Companies Data}

Table 3: Shows independent variables (Debtor Turnover Ration and Inventory Turnover Ratio)

\begin{tabular}{|c|c|c|c|c|c|c|c|c|c|c|}
\hline & 2009 & 2010 & 2011 & 2012 & 2013 & 2014 & 2015 & 2016 & 2017 & 2018 \\
\hline \multicolumn{11}{|c|}{ DEBTOR TURNOVER RATIO (Times) } \\
\hline Ambuja Cement & 26.76 & 36.18 & 27.89 & 28.98 & 26.84 & 25.49 & 22.16 & 20.67 & 24.51 & 18.19 \\
\hline Acc Ltd & 22.37 & 27.55 & 34.89 & 28.59 & 20.31 & 19.26 & 17.10 & 14.34 & 15.17 & 12.31 \\
\hline Shree Cement & 32.65 & 32.55 & 23.11 & 25.08 & 13.80 & 12.97 & 10.33 & 9.82 & 19.35 & 16.21 \\
\hline \multicolumn{11}{|c|}{ INVENTORY TURNOVER RATIO(Times) } \\
\hline Ambuja Cement & 13.70 & 12.16 & 9.25 & 9.89 & 9.81 & 11.23 & 10.57 & 9.81 & 9.94 & 8.89 \\
\hline Ultratech Cement & 9.23 & 8.57 & 6.8 & 8.99 & 8.59 & 8.56 & 8.34 & 9.61 & 10.74 & 9.61 \\
\hline Acc Ltd & 10.30 & 8.36 & 8.79 & 10.02 & 9.96 & 9.35 & 9.92 & 9.12 & 9.46 & 8.82 \\
\hline Shree Cement & 17.59 & 10.13 & 8.54 & 11.72 & 10.54 & 7.27 & 7.02 & 6.76 & 6.54 & 6.27 \\
\hline
\end{tabular}

Source: The given data is taken from annual reports of above-mentioned companies \& Moneycontrol.com 


\section{Measurements and Estimations}

Based on the previous literature the research model is developed that is similar to Efeeloo et al (2020) Study.

To test the hypothesis. Therefore, taking a basic equation of regression will proceed to Panel POLS Regression model.

$$
\text { Yit }=\alpha+\beta x i t \ldots \ldots \ldots \ldots . . . . . . .(1)
$$

Study is applying Pooled ordinary least square (POLS) as intercept is assume same for all firms.

$$
\begin{gathered}
\text { ROAit }=\alpha+\beta x i t+\varepsilon i t \ldots e q-2 \\
\text { oPit }=\alpha+\beta 1(\text { Debtor Turnover Ratio }) \text { it }+\beta 2(\text { Inventory Turnover Ratio })+\varepsilon i t \ldots e q(3) \\
\text { PMS }=\alpha+\beta 1(\text { Debtor turnover Ratio }) \text { it }+\beta 2(\text { Inventory Turnover Ratio })+\text { eit ...eq (4) }
\end{gathered}
$$

\begin{tabular}{|c|c|c|c|c|c|c|c|c|c|c|}
\hline & 2009 & 2010 & 2011 & 2012 & 2013 & 2014 & 2015 & 2016 & 2017 & 2018 \\
\hline \multicolumn{11}{|c|}{ OPERATING PROFIT MARGIN \% } \\
\hline Ambuja Cement & 25.80 & 23.15 & 20.64 & 20.44 & 17.39 & 18.65 & 13.49 & 15.38 & 15.38 & 13.99 \\
\hline Acc Ltd & 29.63 & 19.67 & 16.95 & 13.79 & 12.02 & 10.38 & 7.22 & 7.90 & 9.86 & 14.15 \\
\hline Shree Cement & 17.40 & 26.00 & 12.87 & 15.65 & 43.47 & 16.04 & 8.08 & 9.51 & 15.1 & 16.00 \\
\hline \multicolumn{11}{|c|}{ PROFIT MARGIN TO SALES \% } \\
\hline Ambuja Cement & 17.21 & 17.10 & 14.45 & 13.41 & 14.25 & 15.09 & 8.62 & 10.59 & 11.95 & 13.09 \\
\hline Ultratech Cement & 15.31 & 15.51 & 10.63 & 13.47 & 13.27 & 10.68 & 8.89 & 9.12 & 9.67 & 7.27 \\
\hline Acc Ltd & 20.02 & 14.51 & 13.72 & 9.34 & 9.83 & 9.95 & 5.01 & 5.40 & 6.45 & 10.18 \\
\hline Shree Cement & 21.32 & 18.61 & 6.07 & 10.49 & 17.96 & 13.37 & 6.61 & 8.17 & 13.86 & 13.62 \\
\hline \multicolumn{11}{|c|}{ RETURN ON ASSETS \% } \\
\hline Ultratech Cement & 12.65 & 13.07 & 7.02 & 10.66 & 9.69 & 7.22 & 5.72 & 5.75 & 6.69 & 4.10 \\
\hline Acc Ltd & 15.72 & 9.93 & 11.05 & 8.90 & 9.06 & 9.22 & 4.61 & 4.48 & 6.15 & 9.40 \\
\hline Shree Cement & 21.86 & 17.60 & 4.24 & 10.36 & 16.30 & 10.74 & 5.33 & 5.18 & 11.99 & 9.14 \\
\hline India Cement & 6.13 & 4.52 & 0.86 & 3.55 & 1.86 & 1.86 & 1.74 & 1.67 & 1.63 & 0.94 \\
\hline
\end{tabular}

\section{Equation Explanation}

$$
\text { ROAit }=\alpha+\beta x i t+\varepsilon i t
$$

Table 4: Shows Dependent variables (Operating Profit Margin, Return on Assets and Profit Margin to Sales

Source: The given data is taken from annual reports of above-mentioned companies \& Moneycontrol.com

\section{Whereas}

ROA $=$ Dependent variable measures performance of cement manufacturing companies of Pakistan.

$\alpha \quad=$ measures the intercept line

$\beta=$ measures the coefficient

DTR $=$ Debtor Turnover Ratio is independent variable measures the impact in terms of cash flow.

ITR = Inventory Turnover Ratio is independent variable measures the impact in terms of cash flow.

$\boldsymbol{\varepsilon}=$ Control variable to measure the standard error 


\section{Equation Explanation}

$$
\begin{gathered}
\text { OPit }=\alpha+\beta 1(\text { Debtor Turnover Ratio }) \text { it }+\beta 2(\text { Inventory Turnover Ratio }) \\
+ \text { eit } \ldots \ldots \ldots \ldots \text { eq } \ldots \ldots .(3)
\end{gathered}
$$

Whereas

$\mathrm{OP}=$ Dependent variable measures performance of cement manufacturing companies of Pakistan.

$\alpha=$ measures the intercept line

$\beta=$ measures the coefficient

DTR = Debtor Turnover Ratio is independent variable measures the impact in terms of cash flow.

ITR =Inventory Turnover Ratio is independent variable measures the impact in terms of cash flow.

$\varepsilon=$ Control variable to measure the standard error

\section{Equation Explanation}

$$
\begin{gathered}
\text { PMS }=\alpha+\beta 1(\text { Debtor turnover Ratio }) \text { it }+\beta 2(\text { Inventory Turnover Ratio }) \\
+\varepsilon i t \ldots e q \ldots .(4)
\end{gathered}
$$

\section{Whereas}

PMS = Dependent variable measures performance of cement manufacturing companies of Pakistan.

$\alpha \quad=$ measures the intercept line

$\beta=$ measures the coefficient

DTR $=$ Debtor Turnover Ratio is independent variable measures the impact in terms of cash flow. ITR = Inventory Turnover Ratio is independent variable measures the impact in terms of cash

\begin{tabular}{|c|c|c|c|}
\hline \multicolumn{4}{|c|}{ Estimation technique } \\
\hline & Pooled OLS & REM & FEM \\
\hline DTR & $\begin{array}{c}-0.018596 \\
(0.3104)\end{array}$ & $\begin{array}{c}-0.017178 \\
(0.2438)\end{array}$ & \\
\hline ITR & $\begin{array}{c}-1.401036 \\
(0.0085)\end{array}$ & $\begin{array}{r}-0.122774 \\
(0.8485) \\
\end{array}$ & \\
\hline \multirow[t]{2}{*}{ Breusch-Pagan Test } & Cross- Section & Time & \\
\hline & 0.0000 & 0.5267 & \\
\hline \multirow[t]{2}{*}{ Husman Test } & Chi Square & Prob & \\
\hline & 0.879377 & 0.6442 & \\
\hline
\end{tabular}
flow.

$\boldsymbol{\varepsilon}=$ Control variable to measure the standard error

Table 05: Result for Return on Assets Indicators of Cement firm of Pakistan

Note that the all value in parenthesis all $\mathrm{P}$-value respective significance at $10 \%, 5 \% \& 1 \%$ and these values are above in small brackets. Abbreviation of REM random effect model, FEM Fixed effect model DTR debtor turnover ratio, ITR Inventory turnover ratio. 
Table 5: Explains the results of model equation 2.

$$
\text { ROAit }=\alpha+\beta 1 x i t+\beta 2 i t+\varepsilon \ldots e q
$$

Hence, Coefficient of debtor's turnover ratio (-0.018) shows negative but nonsignificant relationship with ROA here P-value shows (0.3104). while Coefficient Inventory turnover ratio (1.401) shows negatively significant relationship with ROA with P-value (0.0085).

Hence as per Breauch Pagan test hypothesis, results showing for Return on Assets the crosssectional P-Value (0.0000) is significant and time shows non-significant value (0.5267).

As the probability value of cross-section indicates for ROA significant at P-value 0.0000 and time shows insignificant P-value 0.5267, therefore as per Brush Pagan Hypothesis Null Hypothesis is rejected with less than 0.05 probability of cross section.

therefore, test Pooled OLS is not appropriate and required to estimate Random Effect Model / Fixed Effect Model, which can be confirmed from Hussman test that between both REM/FEM which one is appropriate. As per Husman test if P-value is greater than (0.05) study have to accept null hypothesis and go for Random Effect Model

Hence the results of above table illustrated that as the Probability value (0.64) is greater than (0.05) so null hypothesis is accepted; therefore, Random Effect Model is appropriate for the model equation.

Table 06: Result for Operating Profit Performance Indicator of Cement firm of Pakistan

\begin{tabular}{llll}
\hline & Estimation Equation & & \\
\cline { 2 - 4 } & Pooled OLS & REM & FEM \\
\hline DTR & 0.009900 & 0.009900 & $(0.4804)$ \\
& $(0.7179)$ & $(0.6908)$ & 0.014328 \\
ITR & -4.236111 & -4.236111 & $(0.9918)$ \\
\hline \multirow{3}{*}{ Breusch-Pagan Test } & $(0.0000)$ & $(0.0000)$ & \\
& & &
\end{tabular}

Husman Test

\begin{tabular}{cl} 
Chi Square & Prob \\
\hline 12.498213 & 0.0019
\end{tabular}

Note that the all value in parenthesis all P-value respective significance at $10 \%, 5 \% \& 1 \%$ and these values are above in small brackets. Abbreviation of REM random effect model, FEM Fixed effect model, DTR debtor turnover ratio, ITR Inventory turnover ratio.

The above-mentioned estimations explain the results of model equation 3.

OPit $=\alpha+\beta 1($ Debtor Turnover Ratio $)$ it $+\beta 2($ Inventory Turnover Ratio $)+$ eit ...eq (3)

Hence, Coefficient of debtor's turnover ratio (0.009900) shows positive but nonsignificant relationship with Operating Profit here P-value shows (0.7179). while Coefficient Inventory turnover ratio (-4.236111) shows negatively significant relationship with ROA with $\mathrm{P}$ - value (0.0000).

as per Brush Pagan test hypothesis, results showing for Operating Profit the cross-sectional PValue (0.7110) is non-significant and time shows significant value (0.0000).

As the probability value of cross-section indicates non-significant at P-value 0.7110 and time 
shows significant P-value 0.0000, therefore as per Brush Pagan Hypothesis Null Hypothesis is rejected with less than 0.05 probability of cross section.

Hence the results of above table illustrated that as the Probability value (0.019) is less than (0.05) so null hypothesis is rejected; therefore, Random Effect Model is not appropriate for the model equation.so we have chosen to run Fixed Effect Model.

Table 07: Result for Profit Margin to Sales Performance Indicators of Cement firm of Pakistan

\begin{tabular}{|c|c|c|c|}
\hline & \multicolumn{3}{|c|}{ Estimation Equation } \\
\hline & Pooled OLS & REM & FEM \\
\hline DTR & $\begin{array}{r}-0.004291 \\
(0.8626)\end{array}$ & $\begin{array}{c}0.004050 \\
(0.8746)\end{array}$ & \\
\hline ITR & $\begin{array}{l}-2.878461 \\
(0.0001) \\
\end{array}$ & $\begin{array}{c}-2.129152 \\
(0.0165) \\
\end{array}$ & \\
\hline \multirow[t]{2}{*}{ Breusch-Pagan Test } & Cross- Section & Time & \\
\hline & 0.6630 & 0.0000 & \\
\hline \multirow[t]{2}{*}{ Husman Test } & Chi Square & Prob & \\
\hline & 4.804602 & 0.0905 & \\
\hline
\end{tabular}

Note that the all value in parenthesis all $\mathrm{P}$-value respective significance at $10 \%, 5 \% \& 1 \%$ and these values are above in small brackets. Abbreviation of REM random effect model, FEM Fixed effect model, DTR debtor turnover ratio, ITR Inventory turnover ratio.

The above estimations explain the results of model equation 4: hence, Coefficient of debtor's turnover ratio (0.004291) shows positive but nonsignificant relationship with Profit Margin to Sales here P-value shows (0.8626). while Coefficient Inventory turnover ratio (-2.878461) shows negatively significant relationship with ROA with P-value (0.0001).

Brush Pagan test hypothesis results shows cross-sectional P-Value (0.6630) is non-significant and time shows significant value (0.0000). As the probability value of cross-section indicates Profit Margin to Sales as non-significant at P-value 0.6630 and time shows significant P-value 0.0000, therefore as per Brush Pagan Hypothesis Null Hypothesis is rejected with less than 0.05 probability of cross section.

Results of Random effect Model but before interpreting the results study applying Husman test check weather Random Effect Model is appropriate or not as further to proceed for Fixed Effect Model.

Hence the results of Husman test the Probability value (0.09) is greater than (0.05) so null hypothesis is accepted; therefore, Random Effect Model is appropriate for the model equation

Table 07: Result for Return on Assets Performance Indicators of Cement firm of India)

\begin{tabular}{llll}
\hline & Estimation Equation & & FEM \\
\cline { 2 - 4 } & Pooled OLS & REM & 0.294512 \\
& 0.301438 & 0.0002 & \\
DTR & 0.0001 & 0.704133 & \\
& & 0.0071 & \\
\hline \multirow{2}{*}{ BTR } & 0.619416 & & \\
& 0.0409 & Time & \\
& & 0.4610
\end{tabular}




\begin{tabular}{lll} 
Husman Test & Chi Square & Prob \\
\cline { 2 - 3 } & 2.236886 & 0.3268
\end{tabular}

Note that the all value in parenthesis all P-value respective significance at $10 \%, 5 \%$ \& $1 \%$ and these values are above in small brackets. Abbreviation of REM random effect model, FEM Fixed effect model, DTR debtor turnover ratio, ITR Inventory turnover ratio.

The above estimations explain the results of model equations; hence, Coefficient of debtor's turnover ratio (0.301438) shows Positive significant relationship with Return on Assets here Pvalue shows (0.0001) similarly Coefficient Inventory turnover ratio (0.619416) indicates positive significant relationship with Operating Profit with P- value (0.0409).

Hence as per Breauch Pagan test hypothesis explains the results as, ROA has one-way significant pro value that is the Pooled least squire equation for ROA is not appropriate and required further Rem or FEM estimates for appropriateness of model equation.

The results of Random effect Model but before interpreting the results study applying Husman test check weather Random Effect Model is appropriate or not as further to proceed for Fixed Effect Model.

As per the results of Husman test the Probability value (0.32) is greater than (0.05) so null hypothesis is accepted; therefore, Random Effect Model is appropriate for the model equation

Table 8: Operating profit and Profit margin to sale Performance Indicators of Cement firm of India)

\begin{tabular}{llllc}
\hline & \multicolumn{2}{c}{ Estimation Equation } & \multicolumn{2}{c}{ Profit Margin to sale } \\
\cline { 2 - 5 } & Pooled OLS & Prob & Pooled OLS & Prob \\
\hline DTR & 0.274769 & 0.0304 & 0.361931 & 0.0000 \\
ITR & 0.518291 & 0.3368 & 0.377065 & 0.2375 \\
\hline \multirow{2}{*}{ Breusch-Pagan } & Cross- Section & Time & Cross- Section & Time \\
\cline { 2 - 5 } & 0.6704 & 0.8278 & 0.1155 & 0.0825 \\
\hline
\end{tabular}

Note that the all value in parenthesis all P-value respective significance at $10 \%, 5 \% \& 1 \%$ and these values are above in small brackets. Abbreviation of REM random effect model, FEM Fixed effect model, DTR debtor turnover ratio, ITR Inventory turnover ratio.

Table 8: Explain that the null hypothesis of Breusch- Pagan in two-way component is nonsignificant at $\mathrm{p}$ values accordingly. It is concluded that the panel least square is appropriate model and no FEM OR REM is required

\section{Conclusion}

The major goal of this research is to look into the impact of cash flow management on the financial performance of Pakistan's and India's cement industries, A comparative study have been done taking analysis of both selected countries and the findings based on the results analyzed in EViews tool applying Panel Least square regression in which the dependent variables are Return on Assets (ROA), Operating Profit (OP) and Profit Margin to sales (PMS) and independent variables Debtor Turnover Ratio (DTR) and Inventory Turnover Ratio (ITR) to answer the questions and achieve the objectives of the thesis the data has been taken from 2009 to 2018 as both countries follows IFRS International financial Reporting Standards. 
The findings for hypothesis one which studies the relationship between cash flow management practices and performance of cement manufacturing company in Pakistan. The results for independent variable DTR shows negative and non-significant relationship with dependent variable ROA. While the findings for ITR indicated negatively significant relationship in Pakistan cement sector. Hence, it is illustrated from results there is not any long dependency of account receivables rather short term in nature that because no relationship extracted from the data analysis. However, the inventory turns over indicated the negative and significant relationship with ROA which validate the theoretical assumption.

The findings for hypothesis two which studies that cash flow turnover ratios have expected negative significant impact on cement firm's financial performance in Pakistan. The result for independent variable shows DTR non-significant relationship with dependent variable Operating Profit, while the findings for ITR indicated negatively significant relationship in Pakistan cement sector. Therefore, theory suggests that as quick as inventory would sell out the firm will gain enough return as operating profit there for findings shows decrease in inventory turnover and increase in operating returns.

Meanwhile, the findings for hypothesis 3, which studies that there is greater influence of cash flow management practices on cement firm are financial performance in Pakistan. The results for independent variable DTR shows Positive but non-significant relationship with dependent variable Profit Margin to Sales. While the findings for ITR indicated negatively significant relationship in Pakistan cement sector. Hence it is illustrated from results and theoretical description there is not any long dependency of Profit Margin to sales because no relationship extracted from the data analysis. However, the inventory turns over indicated the negative and significant relationship which validate the theoretical assumption.

It is observed from the findings that overall, for all performance indicator due to short term influence of DTR which shows no influence on dependent variables. While Hypothesis for inventory ITR is accepted.

The findings for hypothesis one which studies the relationship between cash flow management practices and performance of cement manufacturing company in India. The results for independent variable DTR shows positively significant relationship with dependent variable ROA. While the findings for ITR significant relationship as well in Indian cement sector. It is observed from the results that there is impact of DTR on ROA.

While the findings for hypothesis two which studies that cash flow turnover ratios have expected negative significant impact on cement firm's financial performance in India. The result for independent variable DTR shows significant relationship with dependent variable Operating Profit. Whereas the findings for ITR indicated positive non-significant relationship in Indian Cement sector. Hence, as theory suggests that as quick as inventory would sell out the firm would gain enough return as operating profit. Therefore, findings show decreasing inventory turnover and increase in operating returns.

The findings for hypothesis three which studies that there is greater influence of cash flow management practices on cement firm's financial performance in India. The results for independent variable DTR shows significant relationship with dependent variable Profit Margin to Sales. While the findings for ITR indicated positively non-significant relationship in Indian cement sector. Hence, it is illustrated from results and theoretical description there is not any long dependency of Profit Margin to sales because no relationship extracted from the data analysis. However, the inventory turns over indicated the negative and significant relationship which 
validate the theoretical assumption.

\section{Recommendations}

- It is to be recommended that firms must reconsider their practices of managing cash flows in order to generate more profitability and generate enough cash to meet their obligations.

- It is observed from the theory that debtor's turnover is important factor for earning and Pakistan cement factors must improve debtor's turnover practices for sales growth and simultaneously earnings.

\section{Practical Contribution}

The study on cement factor contributed to research area and open knowledge corridor for researchers. Additionally, it highlighted key areas that determine weak factors which can impact badly on firms practices and having highlighted areas firms can improve their weakness and improve their practices in cash flow management and hence performance.

\section{Future Research Direction}

- In future, researcher can further explore the study by determining impact of working capital on cement sector by comparing the companies of home country or it can be done at international level.

- This study was done based on two turnover ratios Debtor Turnover and inventory turnover; further researchers can carry this study by including Creditor turnover ratio as this ratio was removed from this study due to unavailability of data, but it has importance in cash flow management practices.

- As this study is based on cement manufacturing sector it is recommended that research can further explore different manufacturing sectors that how cash flow management is impacting performance of different sectors.

\section{References}

Abioro, M. (2013). The impact of cash management on the performance of manufacturing in Nigeria. Uncertain Supply Chain Management, 1(4), 177-192

Almazari, A. A. (2013). The Relationship between Working Capital. British Journal of Economics, Management \& Trade, 146-157.

Amarjit Gill, N. B. (2010). The Relationship Between Working Capital Management And Profitability: Evidence From The United States. Business and Economics Journal, 1-10.

Axmiyan. Cement Industry." http://axmiyanhr.com/sectors.php?sectorID=13". Accessed on September.13,2021.

All Pakistan Cement Manufacturer Association. Cements. "https://www.apcma.com/cement.html”. Accessed on September.12,2021.

ACC Limited. Financial Annual Reports. "https://www.acclimited.com/investorrelations/financial-annual-results". Accessed on February.2,2021

Attock Cment.Financial Reports. "https://www.attockcement.com/investor-relation/\#2". Accesed on Jan.17,2021.

Ambuja Cement.Annual Reports. "https://www.ambujacement.com/investors/annual-reports". Accesed on february.2,2021Dewan Cement. Financial Annual Reports.“http://www.dewancement.com/Financial\%20Reports/ANNUAL\%20REPORT\% 202019.pdf'.Accesed on Jan.12,2021.

Acharya, A. S., Prakash, A., Saxena, P., \& Nigam, A. (2013). Sampling: Why and how of it. Indian Journal of Medical Specialties, 4(2), 330-333.

Allen.A.(2017). The SAGE Encyclopedia of Communication Research Methods. Publishing Company: SAGE Publications Inc.: https://www.researchgate.net/publication/31621555. Assessed April. 12, 2017.

Abeer M. El-Sayed., Aida A. Salman., \&Hosam M. Saleh. (2021). Introductory chapter: Cement 
Industry. DOI: 10.5772/intechopen.95053.

Burns, Robert B. (2000)," Introduction to research methods", Fourth international edition, SAGE publications, ISBN 0-7619-6592-0

Bari, M.A., Muturi, P.W.\&Samantar.P.M.S.(2019). Effect of Cash Management on Financial Performance of Food and Beverage Retailers in Puntland state of Somalia: A Case of Garowe District. International Journal of Contemporary Applied Research.6(3),130-153

Chintha, S.S., Prasad,K.V.(2021) A Study On The Impact Of Cash Management On The Financial Performance Of The Listed Manufacturing Companies From Muscat Securities Market, Sultanate Of Oman. International Journal of Business and Administrative Studies. 7(1),25-35

Dixon, W. J., \& Massey, F. J., Jr. (1951). Introduction to statistical analysis. McGraw-Hill.

Dera Ghazi Khan Cement. Financial Statements. "https:/www.dgcement.com/financial.html". Accesed on Jan.12,2021

Etikan, I., \&Bala, K. (2017). Sampling and sampling methods. Biometrics \& Biostatistics International Journal, 5(6), 00149.

Efeeloo, N., Ofor, T. N., \&Onuorah, V. J. K. J. (2020). Cash Flow Management and Financial Performance of Quoted Oil and Gas Firms in Nigeria. Journal of Accounting and Financial Management E-ISSN 2504-8856 P-ISSN 2695-2211, 6(4), 1-11

Fauji Cements Company Limited. Annual Reports. "https://fccl.com.pk/en/annual-reports/" Accesed on Jan.12,2021.

Hassan, U. O. (2017). Effect of Working Capital Management on Firm' Financial Performance: A Survey of Water Processing Firms in Puntland . Journal of Economics and Sustainable Developmet, 1-11

India Cements Limited. Annual Reports. "https://www.indiacements.co.in/investors-corner. php". Accessed on 2. Feb,2021

James R.K., \& Andrew S. M. (2014). Cash flow management and manufacturing firm financial performance: A longitudinal perspective. Int. J. Production Economics.148(14),37-50

James R.Kroes, A. S. (2014). Cash flow management and manufacturing firm financial performance: A longitudinal perspective. International Journal of Production Economics, $37-50$.

Karadağ, H. (2018) Cash, receivables, and inventory management practices in small enterprises: their associations with financial performance and competitiveness. Small enterprise Research, 25(1) 2-22

Kabir. S. M. S. (2016). FORMULATING AND TESTING HYPOTHESIS. Basic Guidelines for Research.51-73: https://www.researchgate.net/publication/325846748.

Liman, M., \& Mohammed, A. s. (2018). Operating Cash Flow and Corporate Financial Performance of Listed Conglomerate Companies in Nigeria. Journal Of Humanities and Social Science, 23(2), 01-11

Lowhorn, G. L. (2007, May). Qualitative and quantitative research: How to choose the best design. In Academic Business World International Conference. Nashville, Tennessee.

Lucky Cement. Financial Annual Reports." https://www.lucky-cement.com/investorrelations/downloads/financial-reports/"'. Accesed Jan.8,2021.

Money Control. Financials. "https:/www.moneycontrol.com/financials/b\%20and\%20a/balancesheetVI/BAP”. Accessed On February.11,2021Hamza, K., Mutala, Z., \&Antwi, S. K. (2015). Cash Management Practices and Financial Performance of Small and Medium Enterprises (SMES) in the Northern Region of Ghana. International Journal of Economics and Management, 3 (7), 456-480, ISSN 23480386.

Maloney, D. P., \& Masters, M. F. (2010). Learning the game of formulating and testing hypotheses and theories. The Physics Teacher, 48(1), 22-24.

Mutune, M.P. (2014). The Relationship Between Financial Planning and Financial Performance of Cement Manufacturing Firms in Kenya. Unpublished Mba Thesis of School of Business, University of Nairobi. 
Nwarogu, I. A. (2017). Cash Management and Performance of Listed Firms in Nigeria. Journal of Economics, Management and Trade, 1-13.

Ndirangu.L. W (2017). Effect Of Cash Management on The Financial Performance of The Companies Listed at The Nairobi Securities Exchange. Unpublished Mba Thesis of School of Business, University of Nairobi.

Soboleva, Y. P., Matveev, V. V., Ilminskaya, S. A., Efimenko, I. S., Rezvyakova, I. V., \& Mazur L. V. (2018). MONITORING OF BUSINESSES OPERATIONS WITH CASH FLOW ANALYSIS. International Journal of Civil Engineering and Technology (IJCIET), 11(9), 2034-2044.

Sabih Al-Abass, H. (2018). Effect of Working Capital Management on Profitability of Cement Sector Listed Companies. International Journal of Academic Research in Accounting, Finance and Management Sciences, 137-142.

Shree Cement. Financial Results. "https://www.shreecement.com/investors/financials-results". Accessed on February.9,2021.

Salman Sarwat, D. I. (2017). Impact of Working Capital Management on the Profitability of Firms: Case of Pakistan's Cement Sector. Journal of Advanced Management Science.

Shash, A. A., \&Qarra, A. A. (2018). Cash Flow Management of Construction Projects in Saudi Arabia. Project Management Journal 49 (5) 1-16

Thomas, L., \& Krebs, C. J. (1997). A review of statistical power analysis software. Bulletin of the Ecological Society of America, 78(2), 126-138.

Tansey, O. (2009). Process tracing and elite interviewing: a case for non-probability sampling. In Methoden der vergleichenden Politic-und Sozialwissenschaft (pp. 481-496). VS Verlag für Sozialwissenschaften.

Tanveer Bagh, M. N. (2016). The Impact of Working Capital Management on Firms Financial Performance: Evidence from Pakistan. International Journal of Economics and Financial Issues, 1-9.

Thomas, k., Makokha, D. E. N., \&Namusonge, P. G. S. (2019). Impact of cash flow management on the performance of agricultural firms in trans-nzoia county in kenya: a case of agricultural development corporation- Kitale. International Journal of Recent Research in Social Sciences and Humanities (IJRRSSH),2(6),173-178.

Ultratech Cment. FinanciaL Annual Reports, "https://www.ultratechcement.com/investors/financials". Accessed on February.2,2021.

Vuran.B., Adiloglu.B.(2018). The Relationship Between Cash Gap and Profitability: An Empirical Study from Turkey. Journal Of Business Economics \& Finance.7(3),288-294

Wadesango, N., Tinarwo, N., Sitcha, L., \&Machingambi, S. (2019). The impact of cash flow management on the profitability and sustainability of small to medium sized enterprises. International Journal of Entrepreneurship, 23(2),115-127

Wijewaradana W. P., \&Munasinghe P. G. (2015). Cash Flows and Firm Performance: Some Evidence from the Sri Lankan Firms Cash Flow. Journal of management matters, 2(1), 42-48

Zakari, M. (2016). The Impact of Cash Conversion Cycle on Firm Profitability: Evidence from Nigerian Listed Telecommunication Companies. Journal of Finance and Accounting, 110. 
